\title{
ХОЛОДНЕ ВИТЯГУВАННЯ З ПОТОНШЕННЯМ СТАЛЕВИХ ПОРОЖНИСТИХ ВИРОБІВ
}

Холодне витягування із потоншенням вісесиметричних порожнистих виробів $\epsilon$ широко розповсюджений процес для зменшення товщини стінки та збільшення висоти виробів. Витягування із потоншенням виконується в одній або в 2-3 послідовно розташованих матрицях, при цьому витягування у наступній матриці починається при суттєвому зменшенні зусилля деформування у попередній матриці. Технологія такого витягування проектується на основі виробничого досвіду та експериментальних даних [1-4]. Наведені у вказаних джерелах дані не відповідають вимогам сучасного виробництва, як по продуктивності формоутворення, так і по точності форми та розмірів виробів, а також містять мало інформації по механічних властивостях здеформованого металу. Використання метода скінченних елементів (МСЕ) для проектування формоутворюючих процесів листового штампування, зокрема процесів витягування, дозволяє отримати всі необхідні дані для проектування технології та суттєво скоротити час на підготовку виробництва [5]. Одним із напрямків інтенсифікації процесів витягування із потоншенням полягає в зниженні зусилля деформування, яке прикладається до донної частини порожнистого напівфабрикату, завдяки застосуванню пуансона спеціального профілю [6]. При витягування таким пуансоном забезпечується створення додаткового тягнучого зусилля за стінку здеформованого напівфабрикату, що дозволяє суттєво зменшити осьові розтягувальні напруження в місці переходу стінки у донну частину та значно збільшити ступінь деформації при потоншенні стінки. Приведені дані аналізу за допомогою МСЕ по розподілу інтенсивності деформацій у здеформованому металі по всьому об'єму виробу та з використанням експериментальної діаграми істинних напружень дозволяють прогнозувати межу текучості у стінці виробу. Тому раціональним $\epsilon$ використання МСЕ для моделювання витягування із потоншенням через 2-3 послідовно розташовані матриці та визначення потрібного пропрацювання структури металу холодною пластичною деформацією за декілька переходів витягування для забезпечення отримання потрібних механічних властивостей здеформованого металу у стінці виробу.

Метою роботи є встановлення за допомогою методу скінчених елементів параметрів переходів холодного витягування із потоншенням вісесиметричного порожнистого виробу 3 маловуглецевої сталі із забезпеченням потрібного пропрацювання структури металу пластичною деформацією у стінці виробу для досягнення відповідних механічних властивостей.

Розрахунковий аналіз витягування із потоншенням проводили за допомогою моделювання з використанням скінченно-елементної програми DEFORM та застосуванням пружнопластичної моделі металу, що деформується і циліндричної системи координат. Вказана модель металу дозволяє встановити кінцеві форму і розміри здеформованих заготовок по переходах витягування та визначити зусилля знімання їх із пуансонів. В якості вихідної заготовки iз сталі AISI 1015 взятий порожнистий напівфабрикат у вигляді конусної чашки. Швидкість деформування (швидкість переміщення пуансонів) була 7 мм/сек, що відповідає формоутворенню на гідравлічному пресовому обладнанні. Тертя на контактуючих поверхнях визначали по Кулону з коефіцієнтом тертя $\mu=0,08$. Врахований тепловий ефект при холодному витягуванні. Конусні матриці мали кут $16^{\circ}$ від вісі з висотою калібруючого пояска 3 мм і радіусом заокруглення конусної частини в калібруючий поясок 2 мм.

Форма та розміри половини вихідної заготовки у вигляді конусної чашки з виступами на донній частині, яка розділена на скінченні елементи, приведені на рис. 1. Розрахункові положення деформуючого інструменту в розрізі для першого переходу витягування через три послідовно розташовані конусні матриці показані на рис. 2. Положення інструменту на початку витягування зображене на рис. 2, а. Заготовка 1 розміщена у першій матриці 
2 д діаметром калібруючого пояска 113 мм. Між матрицями 2 і 3 розмішена обойма для зменшення різнотовщинності при формоутворенні. Матриця 3 мала діаметр 110 мм. Між матрицями 3 і 4 також розміщена обойма, в якій встановлені повзушки для знімання напівфабрикату з пуансона. Матриця 4 мала діаметр 109 мм. Деформування заготовки здійснюється пуансоном 5. При опусканні пуансона 4 отримується напівфабрикат 6 (рис. 2, б), а знімання виробу 3 пуансона виконується при його зворотному переміщенні, при цьому торець напівфабрикату спирається на повзушки (рис. 2, в).

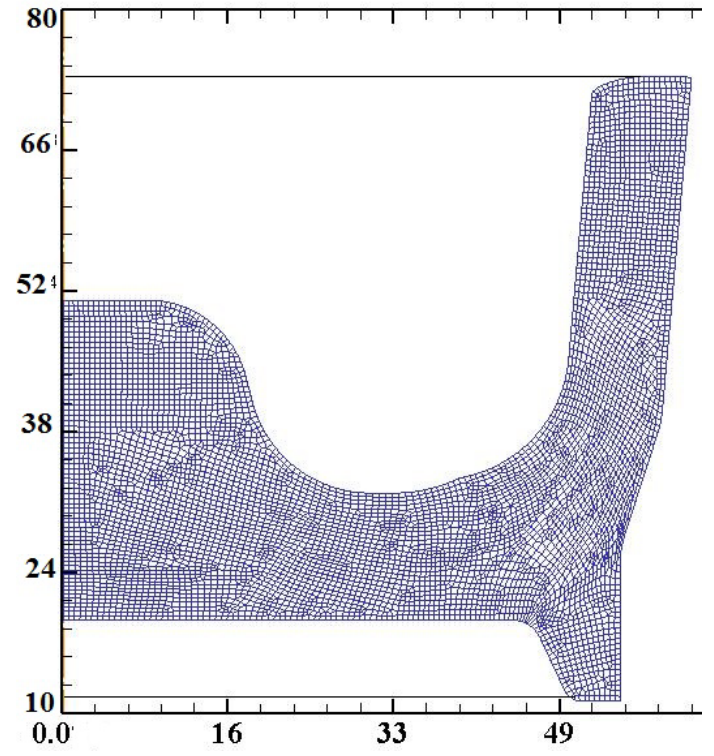

Рис. 1. Форма та розміри половини вихідної заготовки

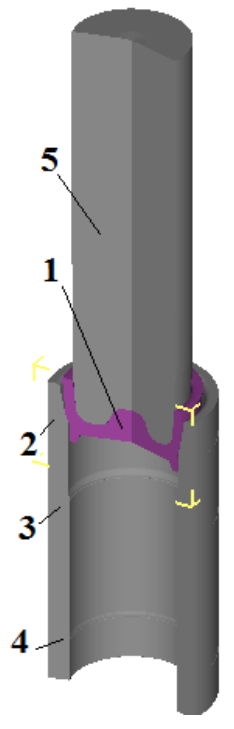

a

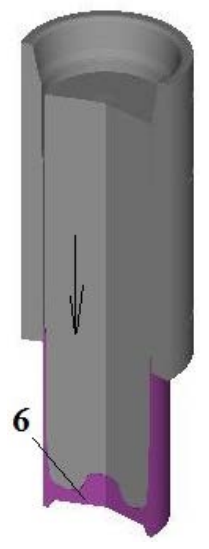

6

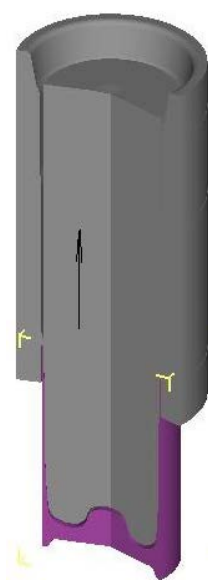

B

Рис. 2. Розрахункові положення деформуючого інструменту для першого переходу витягування: a-на початку витягування, б - в кінці витягування, в - при зніманні напівфабрикату з пуансона

На рис. 3 приведені силові режими першого переходу витягування. Залежність зусилля витягування від переміщення пуансона зображена на рис. За. Зусилля має три максимуми, які виникають при витягуванні у трьох матрицях. У першій матриці максимальна величина зусилля складає $1,46 \mathrm{MH}$, у другій матриці - 1,52 MH, у третій матриці - 1,1 MН.

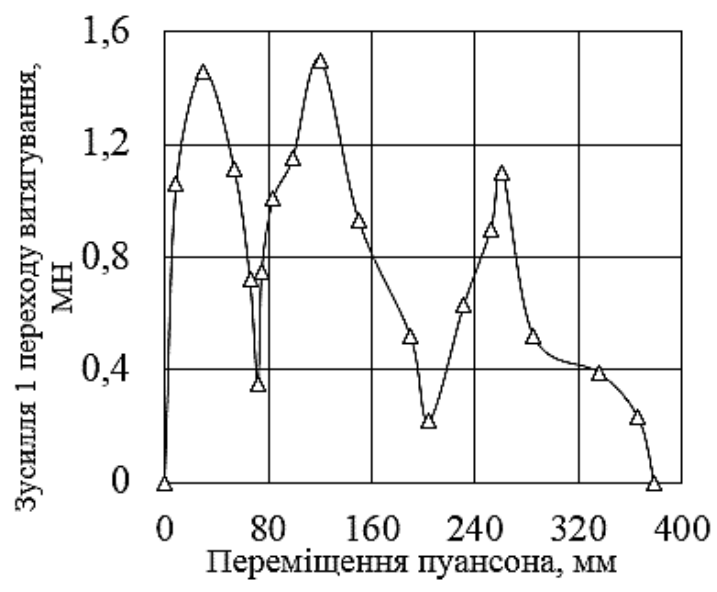

a

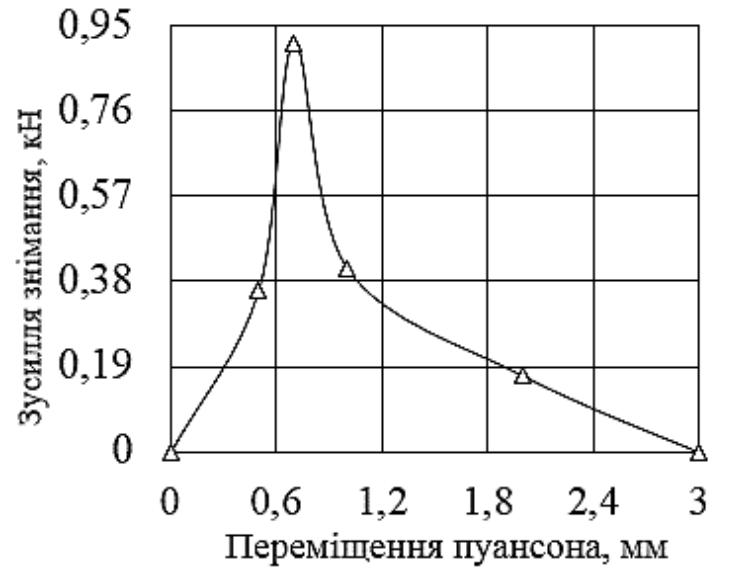

B

6

Рис. 3. Силові режими 1 переходу витягування: a - залежність зусилля видавлювання від переміщення пуансона, б - залежність зусилля знімання напівфабрикату з пуансона від його зворотного переміщення 
Витягування в наступній матриці починається при суттєвому значенні зусилля деформування у попередній матриці. На рис. 36 представлена залежність зусилля знімання напівфабрикату з пуансона від його зворотного переміщення. Максимальна величина зусилля виникає на початку знімання, а повністю знімання здійснюється при переміщенні пуансона на 3 мM.

На рис. 4 показані розподіли нормальних напружень $\sigma_{n}$ на контактуючих поверхнях здеформованої заготовки і деформуючого інструменту при максимальній величині зусилля витягування у першій матриці. Тут і в подальшому на рисунках представлена половина здеформованої заготовки, а тонкими лініями зображений деформуючий інструмент. Наведені розміри першої матриці, обойми між першою і другою матрицями та розміри пуансона. По таких розподілах можна оцінити питомі зусилля на інструменті та прогнозувати його стійкість. На пуансоні виникають напруження до $\sigma_{n}=600$ МПа. Тому пуансони для першого переходу витягування можна виготовляти із сталей Х12M, Х12Ф1. На матриці питомі зусилля досягають величини $\sigma_{n}=1000$ МПа. Для забезпечення надійності та довговічності матриці при експлуатації потрібно виготовляти однобандажованою.

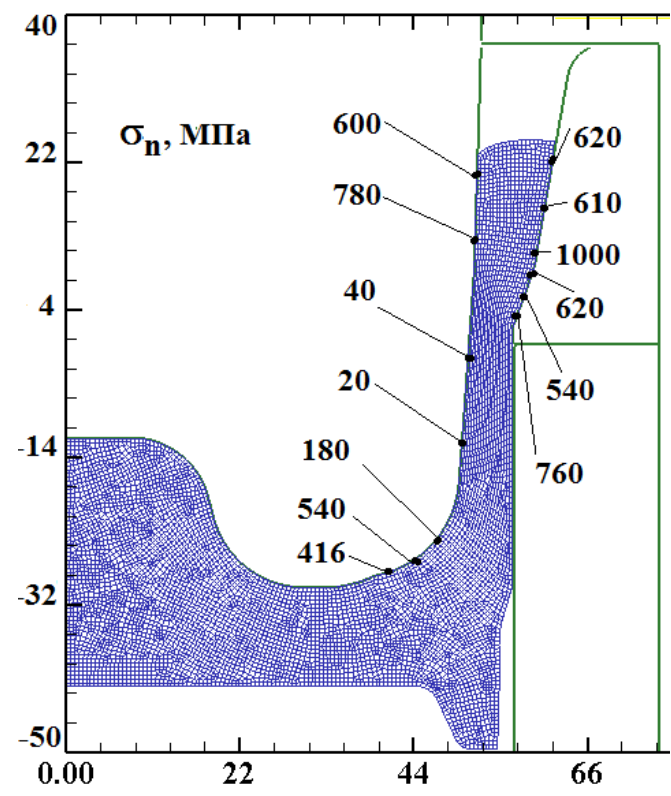

Рис. 4. Розподіли нормальних напружень $\sigma_{n}$ на контактуючих поверхнях здеформованої заготовки і деформуючого інструменту

На рис. 5 зображені розподіл температури $\left(T,{ }^{o} C\right)$, інтенсивності деформацій $\left(\varepsilon_{i}\right)$ та ступеня використання ресурсу пластичності $(\psi)$ у здеформованому металі після завершення витягування у першій матриці. На рис. 5, а показаний розподіл температури. Найбільша величина температури виникає в області торця стінки та досягає $T=180{ }^{\circ} \mathrm{C}$. Пропрацювання структури металу холодною пластичною деформацією можна оцінити по розподілу інтенсивності деформацій $\varepsilon_{i}$, який приведений на рис. 5б. У стінці по висоті отриманий нерівномірний розподіл. Найбільше значення $\varepsilon_{i},=1,3$ отримане у верхній частині стінки зі зменшенням до $\varepsilon_{i},=0,26$ в місці переходу стінки у донну частину. Максимальне значення вичерпаного ресурсу пластичності склало $\psi=0,47$ (при $\psi=1$ починається руйнування металу), що приведено на рис. 5, в.

На рис. 6 зображені розподіл температури, інтенсивності деформацій та ступеня використання ресурсу пластичності у здеформованому металі після завершення витягування у другій матриці. На рис. 6, а показаний розподіл температури. Найбільша величина температури виникає в області торця стінки та досягає $T=140{ }^{\circ} \mathrm{C}$. Зростає пропрацювання структури металу холодною пластичною деформацією. У верхній частині стінки отримано $\varepsilon_{i},=1,8$ (рис. 6, б). 


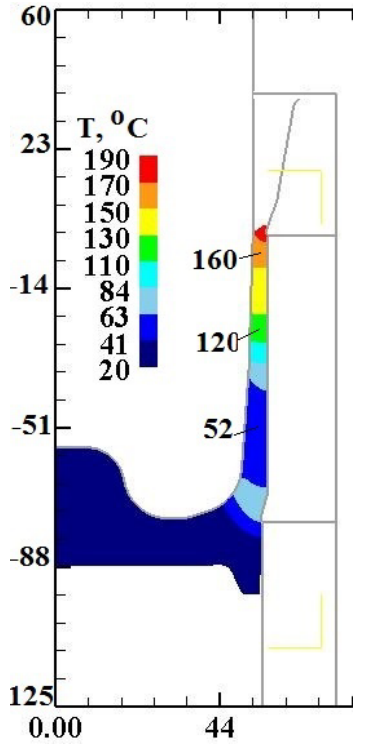

a

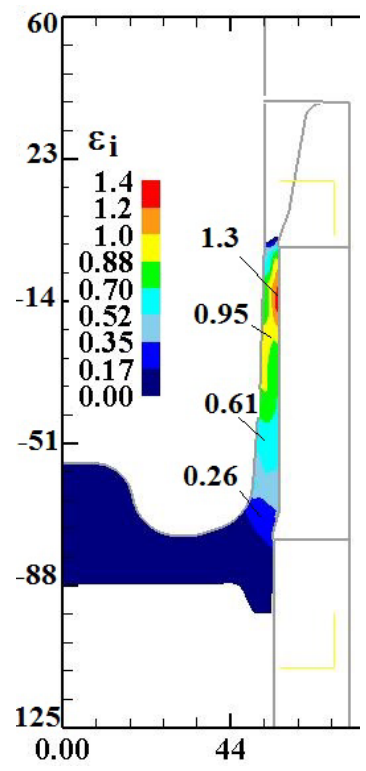

6

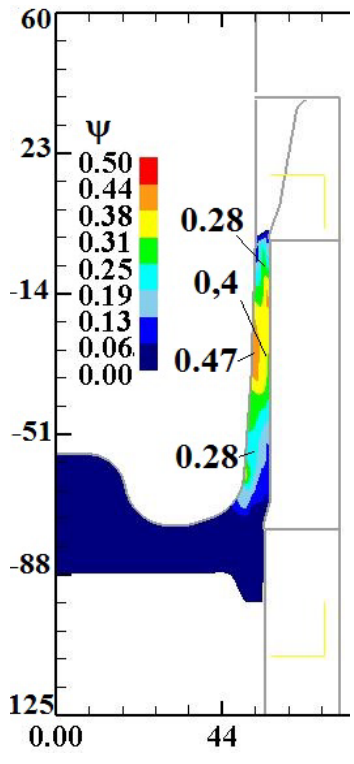

Рис. 5. Розподіли температури $T^{0} C$, інтенсивності деформацій $\varepsilon_{i}$ та ступеня використання ресурсу пластичності $\psi$ у здеформованій заготовці в кінці витягування у першій матриці:

a - розподіл температури, б - розподіл інтенсивності деформацій, в - розподіл ступеня використання ресурсу пластичності

В місці переходу стінки у донну частину величина таких деформацій досягла $\varepsilon_{i},=0,35$. Зростання пропрацювання металу пластичною деформацією приводить до збільшення вичерпаного ресурсу пластичності здеформованого металу, значення якого склало $\psi=0,7$.
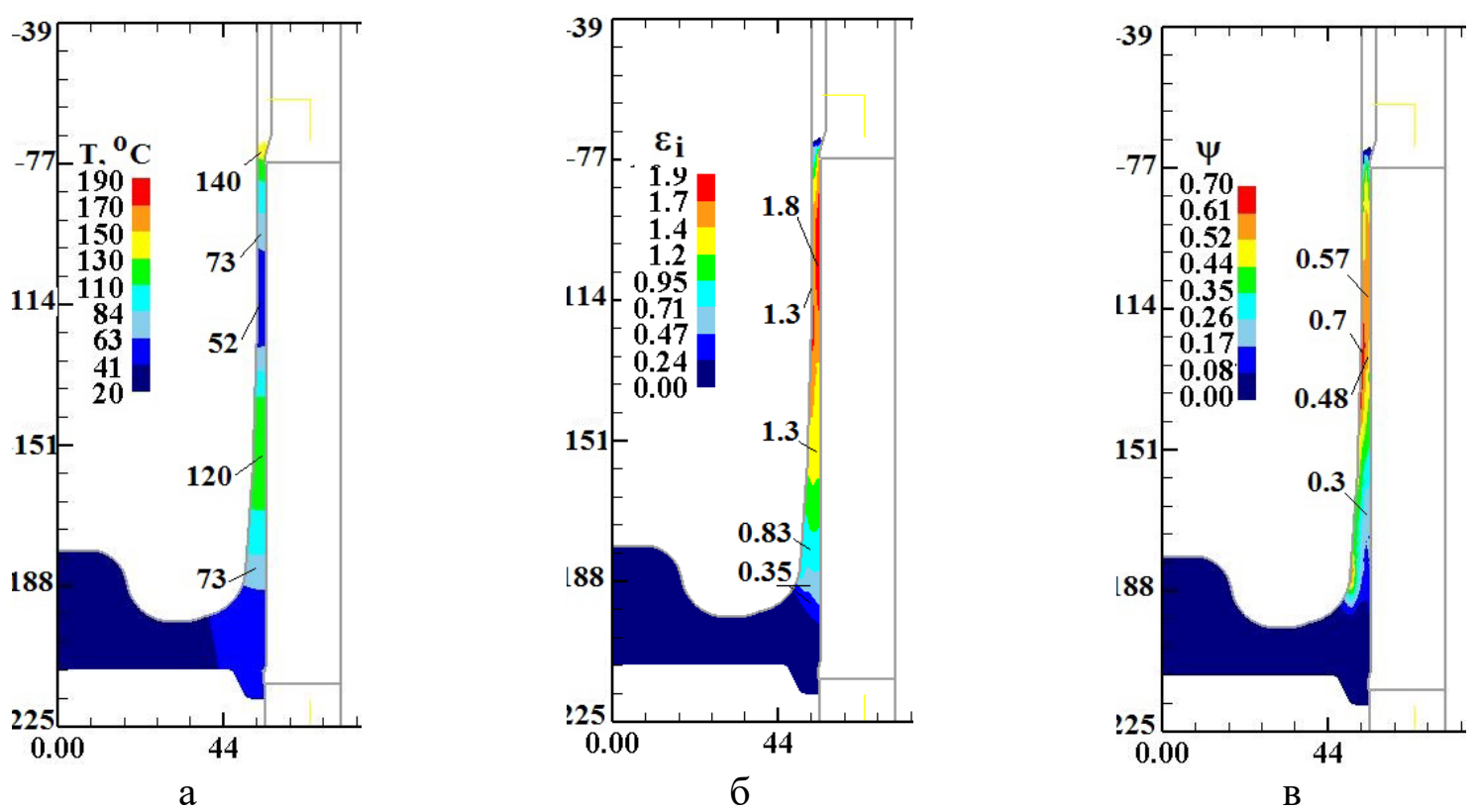

Рис. 6. Розподіли температури $T^{0} C$, інтенсивності деформацій $\varepsilon_{i}$ та ступеня використання ресурсу пластичності $\psi$ у напівфабрикаті в кінці першого переходу витягування:

a - розподіл температури, б - розподіл інтенсивності деформацій, в - розподіл ступеня використання ресурсу пластичності

На рис. 7 зображені розподіл температури, інтенсивності деформацій та ступеня використання ресурсу пластичності у здеформованому металі напівфабрикату, який отриманий на першому переході витягування. На рис. 7, а показаний розподіл температури. Стінка 
здеформованої заготовки охолоджується до температури $T=80{ }^{\circ} \mathrm{C}$, а у донній частині температура підвищується до $T=60{ }^{\circ} \mathrm{C}$. Далі зростає пропрацювання структури металу холодною пластичною деформацією. У верхній частині стінки отримано $\varepsilon_{i},=1,9 \div 2,0$ (рис. 7, б). В місці переходу стінки у донну частину величина таких деформацій досягла $\varepsilon_{i},=0,62$. Зростання пропрацювання металу пластичною деформацією приводить до збільшення вичерпаного ресурсу пластичності здеформованого металу, значення якого склало $\psi=0,9$.

Після першого переходу витягування напівфабрикат підлягає відпалу, тому при моделюванні другого переходу витягування закладені властивості відпаленого металу. Розрахункові положення деформуючого інструменту в розрізі для другого переходу витягування із потоншенням через одну матрицю та доштампування донної частини приведені на рис. 8.

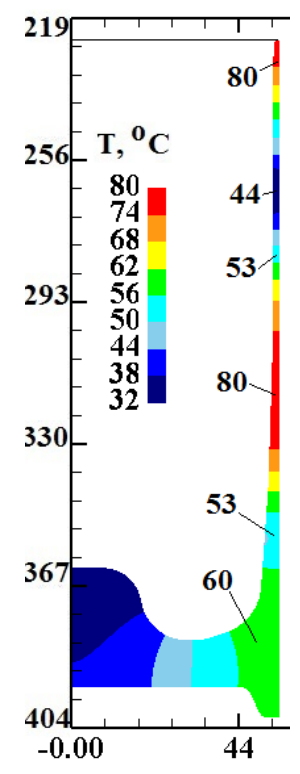

$\mathrm{a}$

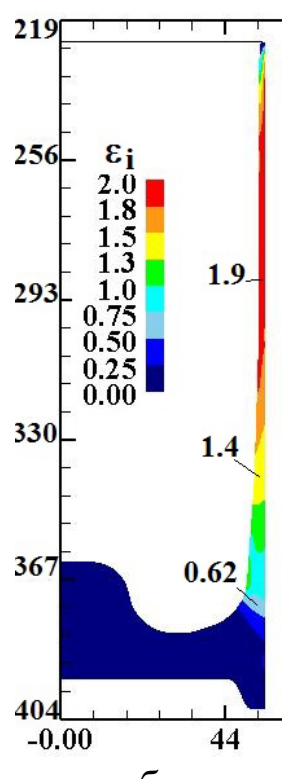

6

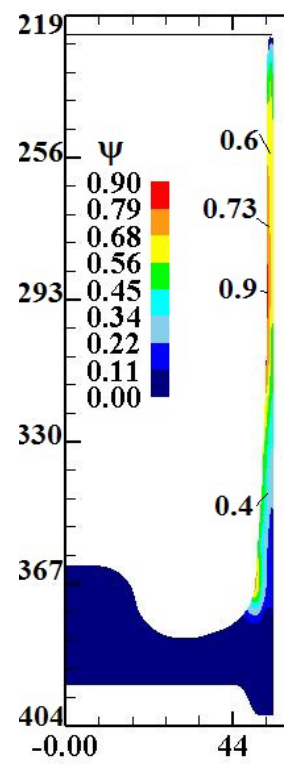

B

Рис. 7. Розподіли температури $T^{0} C$, інтенсивності деформацій $\varepsilon_{i}$ та ступеня використання ресурсу пластичності $\psi$ у напівфабрикаті після першого переходу витягування:

a - розподіл температури, б - розподіл інтенсивності деформацій, в - розподіл ступеня використання ресурсу пластичності

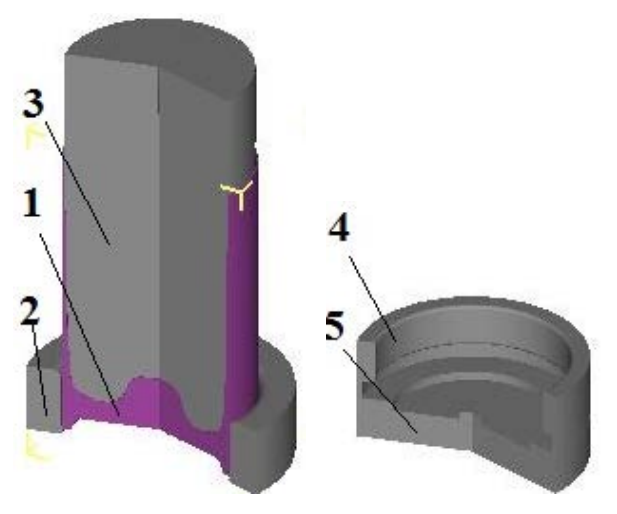

a

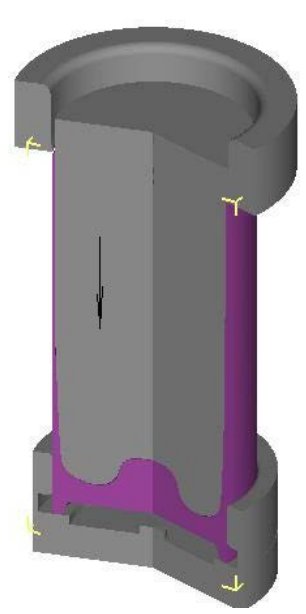

6

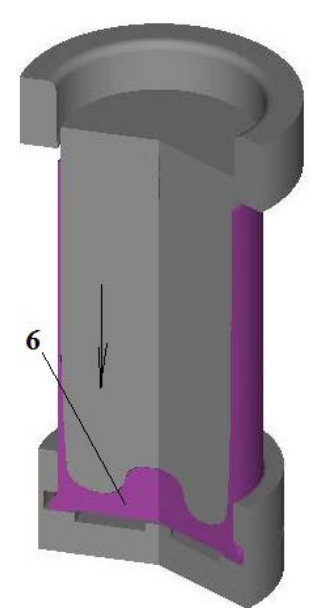

B

Рис. 8. Розрахункові положення деформуючого інструменту для другого переходу витягування:

a - на початку витягування, б - на початку доштампування донної частини, в - в кінці доштампування 
На рис. 8, а представлено положення на початку витягування. Напівфабрикат 1 розміщений у матриці 2. Витягування здійснюється пуансоном 3. Роз'ємна напівматриця 4 та плита 5 для доштампування донної частини розміщені на віддалі, на якій закінчується витягування. Положення на початку доштампування зображене на рис. 8, б.

Здеформований напівфабрикат спирається виступом донної частини на плиту 5, а формоутворення фланця виконується у роз'ємних двох напівматрицях і отримується виріб 6 (рис. 8, в). На рис. 9 показана залежність зусилля деформування від переміщення пуансона на другому переході витягування з доштампуванням. Максимальна величина зусилля витягування склала 0,54 МН при переміщення пуансона 21 мм. Доштампування завершується при зусиллі 2,65 MH.

Результати моделювання другого переходу отримання виробу приведені на рис. 10 . Для проектування штампового оснащення і вибору матеріалу для інструменту на рис. 10, а показані розподіли нормальних напружень у місцях контакту здеформованого напівфабрикату з інструментом при найбільшому зусиллі доштампування. Розподіл температури у стінці та донній частині представлений на рис. 10, б. Максимальна температура виникає в області формоутворення фланця. На рис. 10, в зображений розподіл інтенсивності деформацій по висоті стінки. Під величинами цих деформацій у дужках наведені значення напруження текучості, які визначені по експериментальній діаграмі істинних напружень, По висоті стінки ці напруження складають $\sigma_{s}=600 \mathrm{MПа,} \mathrm{в} \mathrm{місці} \mathrm{переходу} \mathrm{стінки} \mathrm{у} \mathrm{донну} \mathrm{частину} \mathrm{-}$ $\sigma_{s}=450 \mathrm{MПа,} \mathrm{а} \mathrm{у} \mathrm{фланці}-\sigma_{s}=720$ МПа.

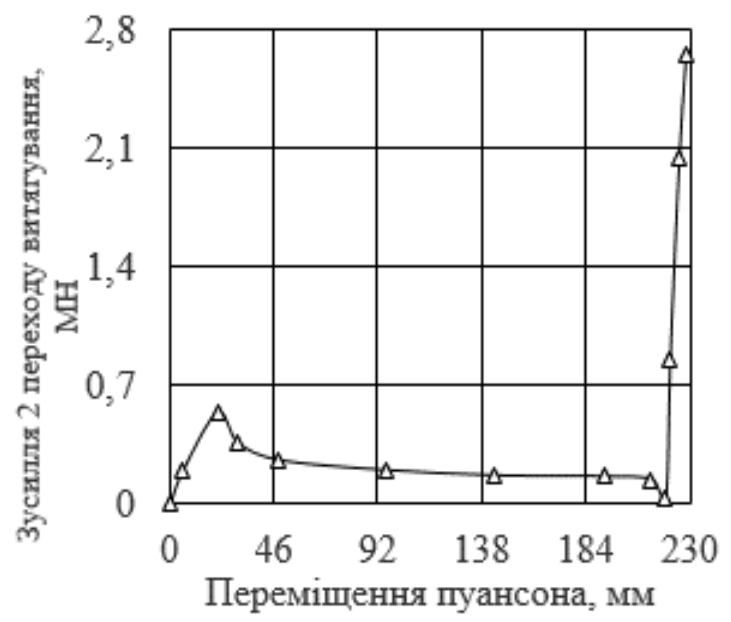

Рис. 9. Залежність зусилля деформування від переміщення пуансона на другому переході витягування 3 доштампуванням

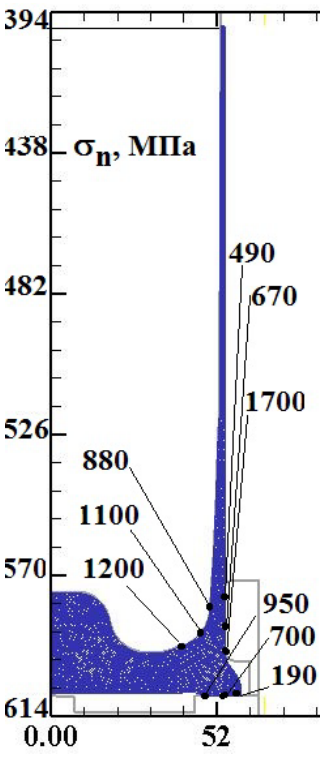

a

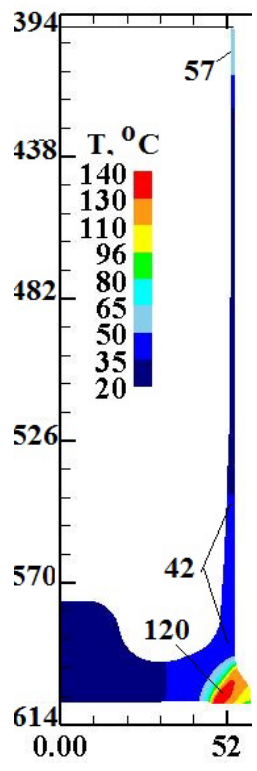

6

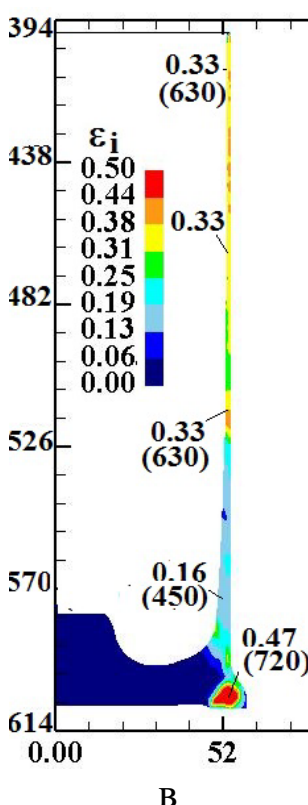

B

Рис. 10. Результати моделювання другого переходу отримання виробу:

a-розподіл нормальних напружень, б - розподіл температури, в - розподіл інтенсивності деформацій

\section{ВИСНОВКИ}

Приведений скінченно-елементний аналіз процесу холодного штампування порожнистого виробу із маловуглецевої сталі з інтенсивним пропрацюванням пластичною деформацією стінки. На першому переході витягуванням із потоншенням вихідної заготовки у вигляді конусної чашки через три послідовно розташовані матриці отримується порожнистий напівфабрикат. На другому переході витягуванням із потоншенням через одну матрицю і доштампуванням донної частини забезпечені кінцеві форма і розміри виробу На кожному переходу встановлені зусилля деформування, розподіл питомих зусиль на деформуючому 
інструменті. Пропрацювання структури металу пластичною деформацією оцінене за величиною інтенсивності деформацій. Для цього показані розподіли інтенсивності деформацій у напівфабрикаті на першому переході, а також у виробі після доштампування донної частини. Встановлені ступені деформації для здійснення витягування із потоншенням через три матриці та через одну матрицю з досягненням межі текучості потрібної величини у здеформованому металі виробу. Приведені розподіли температури здеформованого металу при холодному формоутворенні. Виявлені кінцеві форма і розміри виробу.

\section{СПИСОК ВИКОРИСТАНОЇ ЛІТЕРАТУРИ}

1. Романовский В. П. Справочник по холодной штамповке. 6-е изд., перераб. и доп. Ленингр. отд-ние: Машиностроение, $1979.520 \mathrm{c}$.

2. Ковка и штамповка: Справочник: В 4 т. Т. 4. Листовая штамповка / Под ред. А. Д. Матвеева; Ред. совет: Е. И. Семенов (пред.) и др. Москва: Машиностроение, 1985-1987. 544 с.

3. Аверкиев Ю. А., Аверкиев А. Ю. Технология холодной штамповки. Москва: Машиностроение, 1989. $304 \mathrm{c}$.

4. Попов Е. А., Ковалев В. Г., Шубин И. Н. Технология и автоматизация листовой штамповки. Москва: Изд-во МГТУ им. Н. Э. Баумана, 2003. 480 с.

5. Калюжний О. В., Калюжний В. Л. Інтенсифікація формоутворюючих процесів холодного листового штампування. Київ: ТОВ «Сік Груп Україна», 2015. 292 с.

6. Калюжний О. В., Соколовська С. С. Визначення параметрів витягування з потоншенням зпрофільованим пуансоном порожнистих заготовок після видавлювання. Вісник НТУ «ХПІ»: Серія «Інноваційні технології та обладнання обробки матеріалів у машинобудуванні та металургї̈. Харків: НТУ «ХПІ», 2017. № 36 (1257). C. 21-28.

\section{REFERENCES}

1. Romanovsky V.P. Handbook of cold stamping. Leningrad: Mechanical Engineering. 1979. 520 p. (in Russian).

2. Forging and stamping. Handbook. In 4 t., T. 4. Sheet stamping. Ed. Matveev A.D. Moscow: Mechanical Engineering. 1987. 544 p. (in Russian). (in Russian).

3. Averkiyev A.Yu., Averkiyev Yu.A. Cold Stamping technology. Moscow: Mehanical Engineering, 1989. 304 p.

4. Popov E.A., Kovalev V.G., Shubin I.N. Sheet metal stamping technology and automation. Moscow: Publisher MGTU named N. Baumana. 2003. 480 p. (in Russian).

5. Kaliuzhnyi A.V., Kaliuzhnyi V.L. Intensification of forming operations of sheet stamping. Kyiv: Cik Grup Ukraine. 2015. 292 p. (in Russian).

6. Kaliuzhnyi A.V., Sokolovska S.S. Determination of the parameters of extrusion with thinning of hollow blanks after extrusion with a profiled punch. Bulletin of the NTU “KhPI”. Kharkiv: NTU “KhPI”. 2017. №36(1257), pp. 21-28. (in Russian).

Калюжний О. В. - канд. техн. наук, доцент, директор ITEA;

Калюжний В. Л. - д-р техн. наук, проф. НТУУ «КПІ»;

Картамишев Д. О. - аспірант ДДМА.

ITEA - Навчальний центр ITEA (IT Education Academy), м. Київ.

НТУУ «КПІ» - Національний технічний університет України «Київський політехнічний інститут імені Ігоря Сікорського», м. Київ.

ДДМА - Донбаська державна машинобудівна академія, м. Краматорськ.

E-mail: kwl_2011@ukr.net 